Derleme Makalesi/Review Article

ORGANIZATIONAL ETHNOGRAPHY WITH FEMINIST
PERSPECTIVE

ABSTRACT: This study aims at presenting a methodological discussion that might assist researchers in identifying the problems encountered by women in a working life dominated by men. Gender has a long debated and studied theme in organizations. Similarly, the discrimination based on gender differences is still on the agenda of working life and it involves a lot of factors that are worth researching. In this study, the author will present information about organizational ethnography that might be applied by the researchers studying gender in organizations.

Key words: Woman, qualitative study, organizational ethnography.

ÖZ: $\mathrm{Bu}$ çalışma, erkek egemen çalıșma yaşamında konumlanan kadınların, yasadıkları sorunları farklı bir açıdan görmeyi sağlayabilecek bir yöntem tartışması yapmayı amaçlamaktadır. Örgütlerde cinsiyet konusu uzun zamandır tartışılan ve araştırılan bir konu olarak karsımıza çıkmaktadır. Özellikle çalışma yaşamında kadının yaşadığı ayrımcılık uygulamaları varlığını sürdürmekte ve konu bu nedenle sürekli araştırılabilecek birçok unsuru barındırmaktadır. Bu çalışmada, özellikle örgütlerde cinsiyet konusuyla uğraşan araştırmacılar için kullanabilecekleri örgütsel etnografi yöntemine yönelik bilgiler verilmeye çalışılacaktır.

Anahtar kelimeler: Kadın, nitel araştırma, örgütsel etnografi.

1.

INTRODUCTION

The theme woman has been long studied with references to various points of views and assumptions, and a number of field studies have been conducted to collect data regarding how certain behaviours emerge under specific conditions of working life and how these behaviours are perceived by employees (both males and females). The fact that culture is dealt with through interdisciplinary studies and that it is a significant factor in organizations clearly show how important such studies are. What is crucial here is how the problems faced by women in working life are perceived on the basis of gender perceptions as well as the culture that forms these perceptions. Depending on the patterns formed by society, the place of males and females in working life may differ. Therefore, which methods were already applied in the past and will be applied for future studies carried out on organizations and women have been a significant topic of discussion. The most

Dr. Öğretim Üyesi, Trakya Üniversitesi, ilkeoruc@trakya.edu.tr, ORCID: https://orcid.org/0000-0002-8710-8959 
commonly preferred research method is qualitative study, which uses certain sampling methods suitable for generalizations. Although qualitative studies have started to receive significant recognition from researchers, it is necessary to admit the presence of negative attitudes towards this method as well. Therefore, it is useful to mention about the differences between qualitative and quantitative studies since the method to be discussed in this paper is a qualitative research method. First of all, we should remember that researchers have certain research problems and hypotheses in mind before they start their research. Depending on the research problems, the researcher chooses the best research method that is likely to deal with these problems in the most effective way. In this phase, the decision is taken regarding the research method; whether qualitative or quantitative. In fact, this discussion requires a longitudinal epistemological approach. In order to reject or accept generalizations based on assumptions and deduction, quantitative approach should be used. When the aim is to verify or reject the generalizations based on assumptions and deduction, quantitative methods or logical positivism based on experiments are the best options. However, qualitative and natural methods are more effective in understanding the experiences in a certain environment inductively and holistically (Patton, 1990).

Nowadays, there is a tendecy to blend qualitative and quantitative methods. This tendency is believed to date back the recent criticisims against positivistmodernist approach, which was quite popular in 1930s and 1940s. However, it is also known that these methods were already blended in the fields of psychology and sociology three or four decades ago (Hammersley, 1994). It is a well-known fact that positivist philosophy especially logical positivism has been effective in the progress from the times when these methods were used together to those times when a questionnairre and discourse analysis were considered sufficient. Under the light of these explanations, the differences between quantitative and qualitative research can be listed as follows Table 1 (Hennick et al., 2011:16):

Table 1. Differences Between Quantitative and Qualitative Researh

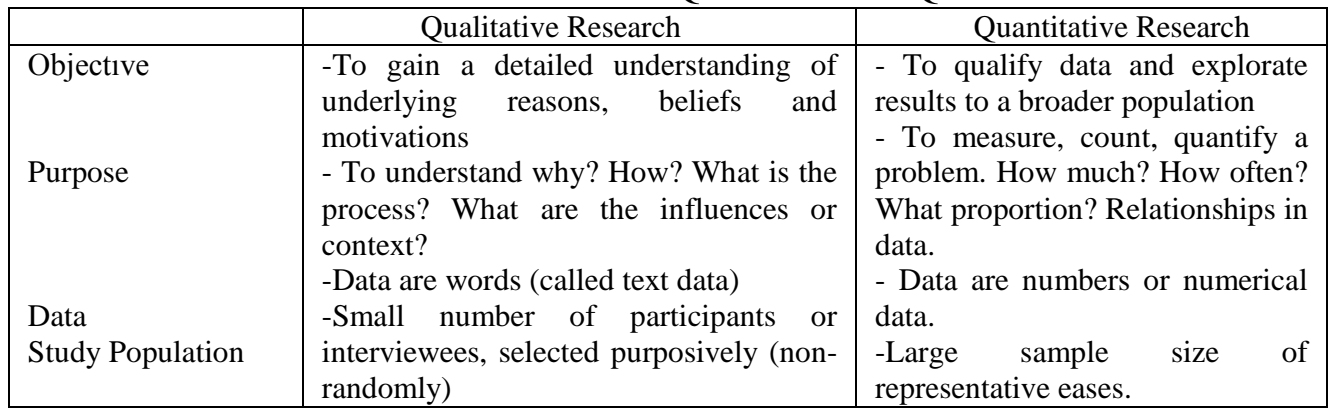


DOI: 10.26468/trakyasobed.531186

\begin{tabular}{|c|c|c|}
\hline $\begin{array}{l}\text { Data collection } \\
\text { methods } \\
\text { Analysis Outcome }\end{array}$ & $\begin{array}{l}\text { Referred to as participants or } \\
\text { interviewees. } \\
\text {-In-depth interviews, observation, group } \\
\text { discussions. } \\
\text {-Analysis is interpretive } \\
\text {-To develop an initial understanding, to } \\
\text { identify and explain behaviour, beliefs } \\
\text { or actions. }\end{array}$ & $\begin{array}{l}\text {-Referred to as respondents or } \\
\text { subjects. } \\
\text {-Population surveys, opinion } \\
\text { polls, exit interview } \\
\text {-Analysis is statistical } \\
\text {-To identfy prelevance, averages } \\
\text { and patterns an data. To } \\
\text { generalize to a broader } \\
\text { population. }\end{array}$ \\
\hline
\end{tabular}
Resource: M. Henni
Publications, First published.

Which of the above mentioned methods will be chosen or whether both methods will be used together or not depend on the nature of the research problem. Therefore, the method to be explained in detail below will only provide some insights for the researchers in determining the research problem. However, it is necessary to explain how we can approach to the problem from a female perspective first.

\section{TAKING A FEMALE PERSPECTIVE}

When a researcher has a research question in his / her mind regarding the place of women in working life, it is necessary to adopt a suitable research method and a theoretical background to base this method. A study without a theoretical framework will have a weak unity. Therefore, when a study is conducted on women in working life, previous studies involving female perspective will help the researcher to establish a theme unity. Adopting a female perspective for the problems of women requires the consideration of many themes covered in feminist literature. What should be kept in mind here is that feminist literature is quite comprehensive.

Defined in many different ways, feminism can be considered a concept focusing on the inequality between two genders and women's having secondary roles in society (Bierema and Cseh, 2003; Kark, 2004). In other words, it is a term by which women started to question their status in the society and to demand certain practices to improve this status (Freedman, 2001:3). Thus, eliminating sex discrimination in social, economic and political environments is the main motive of a committed feminist (Bierema and Cseh, 2003). Feminist theorists have worked on social and political objectives to prevent male theorists from using sexist discourse. In modern philosophy, many notions involve a lot of cultural prejudices against women. Patriarchal theory does not aim at understanding or explaining the social status of women; however, it adds another factor to this status (Gattens, 1991:1-3). Stereotypes are determined according to the differences in cultural expectations and teach (Carless, 1998). The main approach adopted to study these 
expectations focuses on gender differences and uses psychological, sociological and cultural indicators to explain these differences.

The status of women in a society is an acknowledged indicator of the level of civilization in this particular society. Unfortunately, women have never been able to be a valued member of the society even where everybody is considered equal and free. In fact, it is quite interesting that half of the population was neglected while men support equality and social change (Berktay, 2003:41). The history of women is the history of resistance against the pressure of patriarchal system and women's being forcibly confined within the walls of their homes. This resistance became stronger when the search for individual freedom ideals spread to different layers of society during Renaissance and contributed a lot to the struggle of women for equality. This resistance should be examined according to the existing social conditions. Since this systematic point of view differs according to levels of development, women had different social status in developing and undeveloped countries. Despite this difference, all the struggles led by feminist movement are the concerns of all the women in the world. Accordingly, although the struggles of women in Turkey have taken different forms than those in the West, the concepts dealt with are common to a great extent. Although the conditions and the nature of women rights differ depending on the dynamics of the countries, it is necessary to examine various opinions from different parts of the world with regards to improvements in these conditions.

Why do the women who have been often ignored for a long time throughout history felt the need to be involved in certain attempts to equal themselves with the other sex? Have the women ever succeeded in being aware of their secondary role in the society throughout history? We shouldn't ignore the fact that this situation is the outcome of a sociological movement. What stand out during this process are some radical changes in the lives of women such as increasing their level of education, gaining economic freedom by being a part of working life, selfrealization and being involved in the struggles to obtain equal rights with men. If we analyse the developments related to this issue, we see that the first attempts for equal rights were triggered by the women who belonged to the bourgeois class. The reason lying behind this fact is likely to be that the conditions they live in were quite different than other women. The changing conditions lead to certain developments in different layers of the society such as feminist movements and practices. Since these developments were very comprehensive and required detailed explanations, it is useful to mention about these movements within a limited framework. Similarly, there were considerable differences among authors 
in dealing with the issue and among the studies conducted. The researchers find it hard to categorize the studies and ideas into a framework in feminist terms.

Moreover; feminist approach facilitates the improvement of women's position not only in society but also in organizations. The claim that women can be equal to men forms the basis for all feminist theories (Calas et al., 1993). When we consider the fact that feminist ideas influence many fields, it is necessary to mention about all the basic point of views related to the issue in order to come up with a specific one. The researcher can decide on a basic structure for his / her research question according to many factors involved in feminism (such as feminist ethics and other theoretical approaches towards feminism), which might bring a special perspective to the issue and to the research question. However, how the researcher will deal with these and make his / her choice about the method to be used are likely to change according to the amount of knowledge obtained about comprehensive feminist framework mentioned below. The basic feminist approaches, which might provide a starting point in terms of theoretical framework, will be explained below in detail.

Since most of the modern feminist theories emerge as the outcome of the reactions towards traditional liberal feminism, the concept liberalism can be considered the most distinctive factor in defining feminist principles (Tong, 2006:10). Finally, liberal feminism is divided into traditional and modern paradigms, and traditional liberals support classicism and freedom while liberal feminist's welfare or equality (Kandal, 1988:5)

It is possible to say that traditional liberal feminists share the following basic ideas (Donovan, 2007:27):

1. Traditional liberal feminists suggest that females and males are furnished with the same reasoning ability. In historical perspective, the strong reactions towards the claim that females are less intelligent than males have been the most prominent point of view taken by feminists.

2. The best way to have an effect on social change and social transformation is to provide equal educational opportunities for both women and men. Especially, receiving critical thinking education is believed to be crucial.

3. From social perspective, they supported the idea that women should be given the same political and legal rights as men regarding the issues that restrict the freedom of women such as the right of ownership (inheritance) and the right to elect or to be elected.

The proponents of liberal feminism see the inequality in education as a significant starting point for their arguments. The person who focused on working life in this school of thought is Betty Friedan. In her study titled Feminine 
Mystique, Betty Friedan mentions about the difficulty of being a mother and having a carrier at the same time. Focusing on family-work conflicts, the book emphasizes the smooth integration of carrier and family, which is a significant issue discussed even today (Friedan, 1983). Written in 1980, the book titled The Second Stage by Friedman deals with various issues such as the problems of women having multiple roles, public values and individual achievement goals and the effects of women's working together with men in the same working environment (Ollenburger et al., 1992). In short, such studies by Friedman might provide a starting point for a researcher with a research question in his / her mind about family-work conflicts.

Unlike classical liberals, modern liberal feminists discussed the claim that the women favoured by patriarchal societies should focus only on the jobs suitable for them such as teacher, nurse and civil servant and they are not considered talented in other jobs. These feminists suggest that gender-stereotype restrictions lead to inequality and such inequalities should be certainly eliminated. In other words, they struggle against discrimination by advocating the idea that women and men should have equal rights. In addition, they state that it is necessary to focus on certain issues such as sex differences, social gender roles, freedom and equality. These discussions have greatly contributed to the clarification of a lot of concerns about inequality-focused studies in the management literature. Such theories provide many insights to help us explain many situations such as family-work conflicts that emerge due to the involvement of women in working life, women's being expected to work in jobs considered as jobs for females, and the difficulty to take part in a male dominant working areas.

Marxists feminists claimed that it is essential to consider certain issues such as the labour of women at home, their receiving low wages at work as employees and family doctrines contributing the oppression of women (Barnett 1998:26-34; Smith 1993:5). The key difference between Marxist feminists and the other feminists is that fact that capitalism or class pressure is the primary pressure (Evans, 1986:113; Massey, 1989:692). It is claimed that class pressure brings down the women to lower positions in working life. Marxist feminists also assume that only economic pressure can completely eliminate patriarchal structure. Therefore, they suggest that it is essential to remove class-based inequality and realize a radical social change to transform the society as a whole (Ollenburger et al., 1992)

The basic point supported by Marxist feminist authors is the roles of women in family life and the pressures on them in public spaces. Some of these authors focused on the demand that housework should be paid, which is still being discussed today. They also emphasize that women should participate in working life and the daily housework should be considered valuable. According to Mies 
(1988), production under the influence of capitalism embitters sex discrimination at work or keeps the women away from social life. More rapid spread of new technologies worldwide negatively affects women and her family. The role of women is confined by patriarchal structure, and unlimited mobility of production powers destroy traditional handcrafts production once carried out by women (basket making and knitting etc). However, the mostly criticized point of this approach is that it focuses on class pressure rather than sex discrimination.

Although the studies on women's place in working life suggest that women should be paid for housework, it is clear that this is not an accepted practice in today's world. The involvement of women in working life does not reduce their responsibilities at home. In fact, the transfer of technology to underdeveloped countries limits the jobs where women can work. The investments on the countries when wages are very low resulted in women's being low-paid labourers in addition to the inequality they already experience. These ideas, which are supported by Marxists, have not been put into practice even in the countries where socialist revolution was realized. Women have resigned themselves to already established systems and continued to fulfil their previous responsibilities at home. The already established patriarchal structure and its position in organizations maintained its existence despite some changes in the current system. Therefore, all the topics discussed should be dealt with by considering various points of view towards women.

Social feminists try to find possible answers to the following question: How can women obtain self-sufficiency unless they free themselves from the hegemony of men although they might have economic freedom? Unlike liberals, they focus on the power differences between males and females. From their perspectives, oppression results from the interaction between capitalism and patriarchal structure. Social feminists reject the dilemma between home and work and emphasize the role of labour at home in the continuity of the exploitation in a classbased society (Ramazanoğlu, 1998:34-35). The basic point discussed by social feminists such as Juliet Mitchel and Heidi Hartman is that sex discrimination is the base of patriarchy. The continuity of patriarchal structure leads to the presence of oppression of women. According to Jaggar (1983), having met with the concept alienation under the influence of capitalism, human activities now prevents women from achieving self-awareness.

Developed by socialist feminists by referring to Marxist feminism, these ideas help us to analyse why women have a secondary importance in working life. The problems faced by women in working life are said to be due to both patriarchal and economic structure. Focusing on women's family and working life, this 
feminist approach has enabled researchers to study this male-female inequality from different perspectives. Influenced by feminist perspectives, these ideas have been quite effective in the emergence of new thoughts and point of views. This new approach also emphasizes the oppression of women in working life and presents us a new perspective to understand the status of women in working life as well.

What forms the basis of radical feminism is that women are suppressed by patriarchal social system. Many forms of pressure such as racism, transsexual life style, heterosexism and class distinction are considered significant in patriarchal pressure relationships. The first condition to free women from pressure is the elimination of patriarchal structure in the society. Social structure is established through historical processes. Therefore, it is quite difficult to change such a structure overnight. Radical feminists emphasize the hegemony of men on women as the outcome of an independent patriarchal system (Freedman 2001:5). When we discuss the nature of pressure, the basic points can be listed as follows (Tong, 1992);

1. Historically speaking, women are an oppressed group.

2. Pressure on women is always ready to be triggered and exists in all societies.

3. Pressure on women is the most difficult one to eliminate. They will never be eliminated by other social changes such as elimination social classes.

4. $\quad$ Pressure on women causes loss of rights.

5. Pressure on women provides a conceptual model to understand all forms of pressure.

Most radical feminists take a standpoint against marriage by claiming that it is an outcome of patriarchal system which is responsible for the pressure on women. According to radical feminists, woman is forced for both motherhood and sexual slavery in marriage. Thus, an important step will be taken to free women from pressures when marriage no longer exists (Ryan, 1992:50). In addition to marriage, patriarchy also strengthens the pressure on women to a great extent. Unfair practices on female body (such as pornography) are seen as the practices that strengthen the myth that female sexuality is passive and masochist but male is active and sadist (Hinmann, 2003:331). So far, language and culture have been arranged according to masculine perspectives. The way woman is presented in the society clearly depicts the hegemony on woman. For instance, a great number of commercials aim at creating an image by using naked women body. It is vital to restructure such practices to ensure a radical change (Coole; 1988:235; Michel, 1993:90). 
DOI: $10.26468 /$ trakyasobed.531186

Radical feminists state that femininity is important and might bring certain advantages and status to women (Çaha, 1996:53). Regardless of class, race and other differences, women are claimed to be exposed to pressure. In such a world where women are embraced and controlled by men and are physically disadvantaged, women are defined as sisters who are suppressed universally (Ramazanoğlu, 1989:13; Ollenburger et al., 1992). According to radical feminists, violence against women forms the basis of patriarchal structure. This pressure often takes the form of sexual assault and sexual harassment practiced by men. The notion of sexual terrorism as a practice of patriarchy results in pressure against women (Ollenburger et al., 1992). Patriarchal pressure is a way of dealing with inequality on women's side. However, feminist philosophers still generate theories to explain this oppression and focus on understanding the concept from different perspectives.

Alfred Adler, an advocate of psychoanalytical feminism, points out that there is clear evidence which supports the idea that all our traditional behaviours, laws, ethics and customs involve male dominance. Those who support this feminist mentality are of the opinion that the practices of our culture regarding gender are influenced by how men perceive themselves and each other, and women are encouraged and even conditioned to assume the role of motherhood in the society (Tong, 2006:229-241, Donovan, 2007:175-221). Trying to explain the existence of women, this approach is a part of currently changing family mentality. In today's modern family structure, responsibilities and labour division are notably changing although traditional family structure is still the dominant one in many parts of the world due to the effects of certain cultural mentalities. The same situation is also observed in Turkey; that is traditional family structure is still maintained and encouraged and motherhood is still a virtue for the society.

Post-structural feminists reject the idea of defining woman. Simone de Beavoir asks the classical post-structural question: Does the woman exist? In terms of cultural feminists, activities and cultural definitions, they do not accept that woman exists. All the approaches involving women also involve restructuring and analysing. It is necessary to make different evaluations rather than the assumptions of patriarchal discourse and traditional dilemmas. According to post-structural feminists, any attempt to define woman is impractical in terms of politics, reaction and ontology. Basically, post-structural feminists compare feminist texts with masculine ones by highlighting the concept difference. The results showed that females were mostly associated with negative characteristics and males with positive ones (Tong, 2006:339-345). This approach to deal with femininity made a difference in terms of feminism. In broader terms, it is emphasized that feminist 
phenomena cannot be examined in this category. It is stated that the issue should be examined in a way to include certain concepts such as culture, social gender, race and sexual orientation. The followers of this approach suggest that certain differences occur not only among genders themselves but also between genders. Female-male conflict is solved through the recognition of its presence. The locally and historically unique issues are examined, pluralism and polysemy are focused on and feminist frameworks are reinterpreted through the reactivation of relativity.

The related studies conducted in Turkey so far have generally adopted quantitative methods to analyse the current situation, and unfortunately ignored the effects of cultural dimensions to a great extent. Thus, the lack of the studies adopting a method aiming at collecting data through direct participation in complex social processes of natural working environment, that is a point of view from the inside, is a significant shortcoming in the related literature. What should be done to compensate this situation or which methods should be adopted? How can a study which might include a female perspective based on the feminist approaches mentioned above be evaluated or analysed within a cultural environment? Ethnography is a method that might assist researchers in analysing the realities in working life according to cultural bases. The question that should be answered here is what ethnography is.

\section{WHAT IS ORGANIZATIONAL ETHNOGRAPHY?}

Ethnography means writing about people (ethos: people, race or cultural group and graphia: writing, presentation) (Neuman, 2003). Due to the importance of cultural approach, ethnography is defined as the comprehensive discovery and definition of the culture of a particular group of people (Johnston etc, 2004). Ethnography started its journey when Polish ethnographer Malinovski wanted to understand the world of indigenous people with references to their relationships with life. These studies have provided a basis for the generalizations regarding human behaviour and social life by broadening our knowledge about the distribution of variety and diversity of human lives across the world (Kottak, 2008). The basic aim of ethnographic studies is to define and interpret the culture of a particular group. These definitions are based on culture-specific concepts, processes and perceptions (Yıldırım et al., 2005:70). Ethnography can also be defined as the on-field data collection process carried out by the researcher by directly participating in the social and ordinary activities in this natural environment when there is no need to collect data systematically (Brewer, 2000:6). Ethnography, as a method, is field-based, personal, multi-factored, longitudinal, inductive, dialogue-based and holistic (Angrosino, 2007). According to Payne and 
Payne (2004), ethnography is a method based on detailed observations of individuals' lives carried out in a systematic way.

There are a lot of studies conducted on organizational ethnography in the foreign literature. These studies aimed at revealing the realities involving the culture of working life by combining organizational field, routines and other events in many areas (Smith, 2007). The researchers studying organizations unfortunately realized the importance of studying daily routines in the organizations quite late since most researchers ignored such routines by assuming that they are insignificant or already established (Schwartzman, 1993). In the ethnographic studies carried out in organizations, the researchers used ethnographic method in order to examine the following situations: how employees use strategies and conceptual tools to finish their work (when they feel the obligation to carry out their tasks superficially in order to finish their tasks in time); how they cope with the demands for productivity and quality at the same time; and how their attitudes change towards administrators and customers at individual and group level. Ethnographers concluded that employees finished their tasks in a different way than dictated by the administrators, and that they did not deliberately share some information with the administrators and engineers, and slow down or block production process, and finally that they played games and collaborated with their co-workers to finish the job (Smith, 2007).

Field researchers observed the relationships among employees, between employees and administrators and among administrators themselves. These observations were in the form of participant observation and the focus points were job satisfaction, donkeywork, informal and unauthorized activities. They tried to explain how such a power emerges which defences the control, experiences conflict and resistance and guides and recreates social equalities (Smith, 2007). Ethnography is required to have a role in the field. This situation sometimes necessitates a sort of negotiation among the groups with different cultural background and interests and an understanding of their mentality. Finally, ethnographic studies have a role of criticism in organizational and socio-economic system by documenting the structure of special groups and organizational world.

V. Maanen (1979), in study on organizational ethnography, suggests that ethnography can be a useful method in generating theories based on realities in organizations. He also emphasizes that ethnographers believe in the effectiveness of participating in organization field directly (through participant observation). In organizational studies, the patterns of interest are typically the various forms in which people manage to do things together in observable and repeated ways. As mentioned earlier, ethnographic studies aim at defining these communities in detail 
by using certain advantages such as face-to-face communication, direct participation in some group activities, document analysis, informants who provide more valuable information than questionnaires, and observations. Van Maanen, in his study, rated the data based on representation and process in organizational ethnography. According to this classification, theories and experimentalism were in the first category. At experimental level, he suggests that it is necessary to examine the behaviours as well as the descriptions by the members through observations. The second level includes attitudes, and they are the concepts used by the researcher in order to explain the patterns of the data obtained in the first level. Van Maanen calls this the representation of representation.

Finally, ethnographers have studied how the categories based on gender and race at work can be effectively determined. In such studies, the researchers found that work place studies are insufficient in quantity, and working conditions are formed by class hierarchy and structured in parallel with the control systems of gender and race, and finally there is a close relationship with class power and authority (Smith 2007). A considerably successful study in the field by Kondo (1990) revealed that working in an environment which is structured by gender identity increases sex discrimination, and certain inequality in the amount of salaries is observed. Kitcharoen (2007), in his study, observed how immigrant women survived in working life by maintaining their culture in this new culture. How the women present their culture in other cultures was depicted through some samples (such as Thailand and Chinese restaurants). Similarly, Alvesson (1988) dealt with gender relationship and gender identity through an ethnographic study. Sex discrimination in labour force has foregrounded certain feminine and masculine concepts, which have been quite popular nowadays. Against traditionally gender-blind ways of understanding organization and organizational behaviour - gender relations have been presented as a central aspect of the functioning of business and workplace. The awareness of sex discrimination in working life has increased and the practices are now more clearly observed. The studies on organizations seek for better answers for certain feminine values such as feminist principles and characteristics, the tasks completed intuitively or emotionally, relationships in working places, the lack of broad hierarchy and limited opportunities for carrier (Alvesson, 1998).

Ethnographers also tried to explain how the stratification of gender and race in working places are reproduced and how working places activities based on inequality occur accordingly. Similarly, Acker (1990) claimed that the duties, wages, systems and interactive expectations are structured differently for women and men, and this discrimination is observed in many organizations. Some other 
researchers also found that gendered and radicalized discourses are structured, changed and combined in salary policies, in the values given to members, and in audits and duty definitions (cited by Smith, 2007).

Ethnographic studies revealed the presence of undesired situations such as having prejudices for women, reluctance to work with them, mobbing, restricted promotion etc. Participant observations and interviews help the researcher to go beyond mere numbers and see that inequalities still exist in many categories (Smith, 2007). The notion of gender as a characteristic of individuals in a social category was easily adapted to conventional models of investigation in which theories were tested through examining the relationship between variables. What seem important with regards to organizations are the studies focusing on the variables in organizational theory, level and functions, employment and industry. Acker (1992), in his study about gendering, states the following;

Advantage and disadvantage, use and control, movement and

emotion, meaning and identity have been stereotyped through femininity

and masculinity in terms of the difference between men and women.

The most important outcome of organizational ethnographic studies is the focus on practices. Although this advantage is not often mentioned in theory, there are many themes worth studying in organizations. Organizational ethnographic studies are a combination of transparency and the ability to empathize and establish sincere relationships with people. Approaches and ideas have the capacity to be theorized; however, it is quite difficult to form such a combination. The studies carried out in organizations involve the following issues: interaction with the people in the organization, focusing on empathy and learning as well as local views and the views of others, critical analysis, self-thought and production ability (Alvesson, 1998).

In short, workplace ethnographers, like other ethnographers, create research questions we are generally familiar with. They make permanent and original contributions to social sciences, which analyse the dynamic nature of workplaces, by identifying the routine in complexity as well as the complexity in routines, and by studying power and inequality. This point of view takes the following issues into consideration: organization, responsibilities, duration of work, relationships and the thing that cannot be realized with the current working methods (Smith, 2007). Although the importance of these issues have not been realized yet, they are crucial, indeed (Scwatrzman, 1993).

Conducting a study based on qualitative study principles requires detailed planning and acting accordingly. The use of ethnography in a study on women in organizations also requires a grounded theoretical framework, a sound research design, data collection tools, effective analysis methods and validity-reliability 
calculations. Research design starts with the determination of research question and related questions and then follows a cyclical process. There are various data collection methods that might be applied in an ethnographic study to be carried out in organizations such as field notes, reflective journals, informal interviews and participant observation. Among those, participant observation is the most important data collection method. Researchers choose among these options depending on their research design. Although it is believed that providing detailed information about these tools will be useful to guide researchers who are planning to apply quantitative research methods, it will increase the length of this paper considerably. Organizational ethnography might provide valuable information not only for the place of women in working life but also for many other themes. Therefore, researchers should benefit from the advantages of ethnography in approaching to organizations not only sociologically and also in terms of the dynamics of organizations as well.

\section{RESULT AND SUGGESTIONS}

So what are the reasons of prejudices against ethnographic studies? First of all, quantitative method is considered more valid in academic contexts since they produce generalizable results. Secondly, ethnographic studies require longer processes and full participation of the researcher. In addition, it conflicts with quantitative methods since it involves subjective evaluations, and the nongeneralizable results cannot be repeated. Finally, it follows a complex research process since it rejects already existing theories and is based on reaching the general from specific (Machin, 2002). Despite above mentioned concerns, conducting research to study women in organizations based on ethnography can be considered meaningful. Not all the knowledge in foreign literature can provide reality for all contexts since they are difficult to apply in different cultures identically and it can even result in failure in some cases. Moreover, the life in the organizations is likely to be directly influenced by the culture of that particular society. As highlighted in the above mentioned ethnographic studies on gender, the attitudes towards women in a society structured according to masculine values are also observed in organizations and affect the prejudices of the individuals in this particular organization. Especially, the communication within the organization, work structures and hierarchical relationships are among those that are affected the most. Thus, it will be useful to conduct a study that takes all of the above mentioned concerns into consideration as a whole, and that tries to explain how women position themselves and men position women in the organizations with 
references to social patterns and direct observation data, and that provides real data in social world.

With the help of ethnographic studies, the situational realities in organizations can be studied on the basis of interactions. The use of this method enables researchers to see the dynamics of social relationships (among the employees and with administrators) more clearly. In addition, it is easier to see the structure embedded in the interactions between genders. In other words, ethnographic studies might present data based on daily realities about the relationship structure that is structured according to genders and whether the relationships between administrators and employees are structured on the basis of gendering.

In today's world, job satisfaction, gender and commitment are considered significant factors in organizations and they are worth studying. Although such studies are structured according to quantitative methods and the data obtained from the employees, they cannot provide sufficient information about how they are applied in real contexts. Due to gender structures in organizations and the realities regarding how organizations are positioned according to dominant cultural factors and many other reasons, the use of ethnographic method while studying on women in working life will bring valuable contributions to research in this field.

It will be useful to apply ethnographic method to understand the practices of discrimination against women as a social phenomenon holistically with regards to relationships and practices in organizations. Focusing on the observation of realities in limited environments, this approach unfortunately has limitations such as subjectivity of the observer and non-generalizable results although it enables the researcher to develop a point of view for the researched topic. Nonetheless, this approach is considered important by researchers since it involves the reflection of the reality of organizations inductively.

\section{REFERENCES}

Acker, J. (1992). Gendering organizational theory. Gendering Orgnaizational Analysis, (Ed. A. Mills ve P. Tancered), London: Sage Pub.

Alvesson, M. (1998). Gender relations and identityat work: a case study of masculinities and Femininities in Adversiting Agency. Human Relations, 51(8), 969-1005.

Angrosino, M. (2007). Doing ethnographic and observational research (Ed. By Uwe Flick), SAGE Qualitative Research Kit.

Barnett, C. (1998). The cultural turn: fashion or progress in human geography? Antipode, 30, 379-394.

Berktay, F. (2003). Tarihin cinsiyeti. İstanbul: Metis Yayınc1lık. 1. Baskı. 
Bierema, L.L. ve Cseh, M. (2003). Evaluating AHRD research using a feminist research framework. Human Resource Development Quarterly. 14(1), 5-26.

Brewer, J.D. (2000). Ethnography. NY: Open University Press.

Calas, M.R. ve Smircich, L. (1993). Dangerous liaisons: the feminine-inmanagement meets globalization. Business Horizons. 36(2), 74-81.

Carless, S. A. (1998). Gender differences in transformational leadership: an examination of superior, leader and subordinate perspectives. Sex Roles, 23(7/8), 413-419.

Coole, D.H. (1988). Women in political theory: from ancient misogyny to contemporary feminism. Lynne Rienner Publisher.

Çaha, Ö. (1996). Sivil kadın. Ankara: Vadi.

Donovan, J. (2007). Feminist teori: Amerikan feminizminin entellektüel gelenekleri. (Çev. Aksu Bora, Meltem Ağduk Gevrek ve Fevziye Sayılan). İstanbul: İletişim Yayınevi, 1. Basım.

Evans, J. (1986). An overview of the problem for feminist political theorists. (Ed. J. Evans) Feminism and political theory. London: Sage Publications, 1-17.

Freedman, J. (2001). Feminism. Buckingham: Open University Press.

Friedan, B. (1983). Kadınlığın gizemi: kadınlar için yeni bir dönem başlatan kitap. (Çev. Tahire Mertoğlu). İstanbul: E Yayınları.

Gattens, M. (1991). Feminism and philosophy: perspectives on difference and equality. Indianapolis: Indiana University Press.

Hammersley, M. (1994). Introduction to Ethnography. Researching Languagenad Literacy in Social Context. (Ed. By D. Graddol, J. Maybin and B. Stierer). The Open University, 1-17.

M. Hennik, I. Hutler and A. Bailey. (2011). Qualitative research Methods, Sage Publications, First published.

Hinman, L. M. (2003). Ethics: a pluralistic approach to moral theory. Belmont: Thomson and Wadsworht. $3^{\text {rd }}$ ed.

Jaggar, A. J. (1983). Feminist politics and human nature. NJ: Allenheld.

Johnson, B. ve L. Christensen (2004). Educational research: quantitative, qualitative and mixed approaches, USA: Pearson Education Inc., Second Ed.

Kandal, T. (1988). The women question in classical sociological theory. Gainesville: University Press of Florida.

Kark, R. (2004). The transformational leader: who is (s)he? A feminist perspective. Journal of Organizational Change Management. 17-2.

Kitcharoen, P. (2007). An ethnography of restaurant workers: Thai women in England. Asian and Pacific Migration Journal, 16(4), 555-577. 
Kondo, D. K. (1990). Crafting selves: power, gender, and discourses of identity in a Japanese workplace. University Of Chicago Pres.

Kottak, C. P. (2008). Antropoloji: insan çeşitliliğine bir bakıls. (Çev. S. Altunek vd.), Ankara: Ütopya Yayınları.

Machin, D. (2002). Etnographic research for media studies. Great Britain: Arnold Publisher.

Massey, D.B. (1989). Reflection on the debate: thoughts on feminism, Marxism and theory. Environment and Planning. A.21, 692-697.

Mies, M. (1988). Women, the last colony. (Mies, M., V. Bennhodt-Thomsen ve C. Von Verlhof içinde). Zed Books, London.

Michel, A.(1993). Feminizm. (Çev. Şirin Tekeli). İstanbul: İletişim Yayınları, 1. Basim.

Neuman, W. L. (2003). Social research methods. qualitative and qualitative approaches, USA: Pearson Education, Inc.

Ollenburger, J.C. and H.A. Moore. (1992). A sociology of women: the intersection of patriarchy, capitalism and colonization. New Jersey: Prentice-Hall, Inc.

Patton, M. Q. (2002). Qualitative research and evaluation methods. Thousand Oaks, CA: Sage Publications, 3rd ed.

Payne, G. ve J. Payne. (2004). Key concepts in social research. London: SAGE Publications.

Ramazanoğlu, C. (1989). Improving on sociology: the Ppoblems of taking a feminist standpoint. Sociology. 23(3), 427-442.

Ryan, B. (1992). Feminism and the women's movements: dynamics of change in social ideology and activism. NY: Routledge, Chapman and Hall, Inc.

Schwartzman, H. B. (1993). Ethnography in organizations. Qualitative Research Methods Series 27, A Sage University Paper, USA: Sage Publication.

Smith, R. B. (1993). The paradox of gender voting: An exploratory analysis. Quality\& Quantity. 27(3), 271-289.

Smith, V. (2007). Ethnogrophies of work and work of ethnographers. Handbook of ethnography. (Ed. P. Atkinson, A. Coffey, S. Delamont, J. Lofland ve L. Lofland), 220-233.

Tong, R. P. (2006). Feminist düşünce. (Çev. Z. Çilingirlioğlu). İstanbul: Gündoğan Yayınları.

Tong, R. P. (1992). Feminist thought: a comprehensive introduction. Rotledge.

Van Maanen, J. (1979). The Fact of Fiction in Organizational Ethnography. Administrative Science Quarterly. 24, 539-550.

Yıldırım, A., H. Şimşek. (2005). Sosyal bilimlerde nitel araştırma yöntemleri. Ankara: Seçkin, 5. Bs. 

December 2019 Volume 21 Issue 2 (949-965) DOI: 10.26468/trakyasobed.531186 